Olena Savchuk,

$\mathrm{PhD}$ in Law

Associate Professor at the Department of Law, Faculty of Humanities and Law at National

Aerospace University M.E. Zhukovsky «Kharkiv Aviation Institute»,

ORCID: https://orcid.org/0000-0003-3299-7936

Researcher ID / Publons https://publons.com/researcher/2990692/olena-savchuk/

Profile in Scopus https://www.scopus.com/authid/detail.uri?authorld=57214937899

e-mail: o.savchuk@khai.edu

\title{
Legal Regulation of Criminal Liability for Crimes Agains the Environment
}

The article analyzes the current legislation of Ukraine in the field of criminal liability for crimes against the environment. Special attention is paid to the importance of enhancing criminal liability to ensure, provided by the Constitution of Ukraine as a fundamental law and guarantor of constitutional rights and freedoms of a person and citizen for the crimes against the environment and to compensate for the damage caused by the violation of this right. However, today one of the global problems is climate change owing to strengthening industrial pollution, increasing the number of vehicles, that do not follow environmental standards and other factors that pollute the natural environment.

Key words: environment, crimes against environment, criminal liability.

Formulation of Problem. In accordance with the Constitution of Ukraine, a person, his life and health, honor and dignity, inviolacy, and safety are the highest social value (Article 3), as well as an everyone's right to have safety environment for life and health and for compensation the damage caused by the violation of this right. Everyone is guaranteed the right to free access to information on the environmental condition, quality of products and household items, as well as the right to distribute it. Such information cannot be confidential (Article 50).

At the same time, the Constitution of Ukraine (Articles 13, 16) stipulates that land, its subsoil, atmosphere, water and other natural resources, located within the territory of Ukraine, natural resources of its continental shelf, exclusive (maritime) economic zone are the objects of property rights of Ukrainian. Environmental security and maintenance of the ecological balance on the territory of Ukraine, overcoming the consequences of Chernobyl Disaster (the planetary scale disaster), genetic conservation of Ukrainian is the State duty.

Analysis of Recent Researches. The leading scientists such as Yu. S. Shemshuchenko, A. P. Hetman, E. N. Zhelvakova, V. M. Komarnytskyi, M. I. Yerofeiev, A. O. Andrusevych, N. R. Kobetska, N. R. Malysheva, M. V. Krasnova, S. M. Shershun to some extent dealt with this subject area. A. M. Shulha studied the issue on land resources in the sphere of criminal liability.

The Article Purpose is to develop and improve the current legislation in the figured question regarding the issue on criminal liability.

Main Content Presentation. The process of globalization and social transformations has increased the priority of environmental conservation and

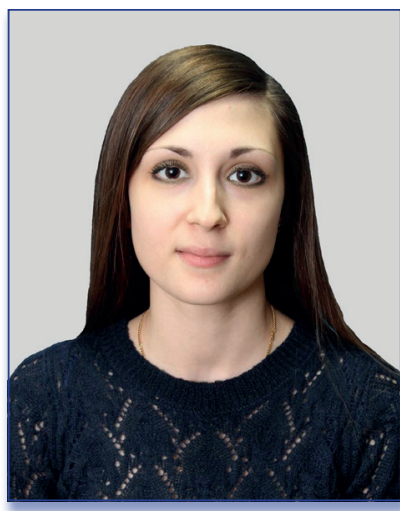

Olena Savchuk

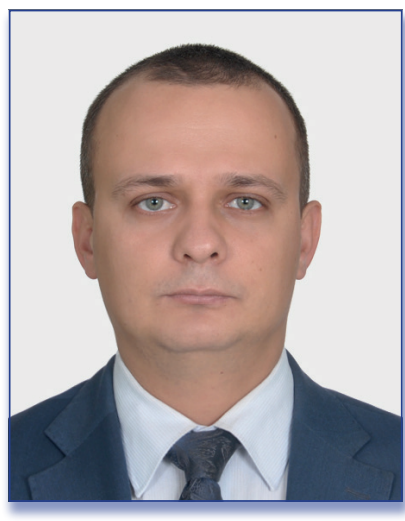

Viktor Butenko

Funding

This research did not receive any specific grant from funding agencies in the public, commercial, or not-for-profit sectors.

\section{Disclaimer}

The funder had no role in the study design, data collection and analysis, decision to publish, or preparation of the manuscript.

\section{Contributors}

The authors contributed solely to the intellectual discussion underlying this paper, case-law exploration, writing and editing, and accept responsibility for the content and interpretation.

Declaration of Competing Interest

The authors declare that they have no conflict of interest. 
О. О. Савчук,

В. Б. Бутенко

ПРАВОВЕ РЕГУЛЮВАННЯ

КРИМІНАЛЬНОЇ

ВІДПОВІДАЛЬНОСТІ 3А

ЗЛОЧИНИ ПРОТИ ДОВКІЛЛЯ

У роботі проаналізовано чинне законодавство України у сфері кримінальної відповідальності за злочини проти довкілля. Акцентовано увагу на важливості посилення кримінальної відповідальності задля забезпечення передбаченого Конституцією України як основоположним законом та гарантом конституційних прав i свобод людини иे громадянина щодо безпечного для життя i здоров'я довкілля та на відшкодуванні завданої порушенням цього права шкоди.

Методами дослідження були загальнонаукові (діалектичний, системний) і спеціальнонауковий методи. Використання діалектичного методу дозволило визначити загальний стан та перспективи дослідження питань правового регулювання кримінальної відповідальності за злочини проти довкілля. Системний м е $\mathrm{T}$ о був використаний у процесі дослідження системи законодавства в окресленій проблематиці. Щодо спеціального методу, тут був обраний метод формально-юридичний, й аналіз чинного законодавства актів України в галузі кримінальної відповідальності за вчинення злочинів у сфері навколишнього природного середовища.

$\mathrm{Ha}$ сьогодні однією із глобальних проблем $є$ зміни клімату у зв'язку 3 посиленням промислового забруднення (надмірна концентрація екологічно виробництв, неефективне природоохоронне обладнання, ненадійні технічні системи й нестача кваліфікованих кадрів на підприємствах із підвищеним екологічним ризиком), значна кількість транспортних засобів, що не відповідають екологічним нормам, та інші чинники, які забруднюють навколишне природне середовище.

Все це є істотними загрозами для глобальної економіки та therefore requires to take urgent measures from the Ukrainian authority. For a long time, the economic development of the State had been accompanying by unbalanced exploitation of natural resources, low priority of issues on the environmental protection that made it impossible to achieve balanced (sustainable) development ${ }^{1}$.

The Association Agreement between Ukraine No 984_011, on the one hand, and the European Union, the European Atomic Energy Community, and their member states, on the other hand, dated on 27.06.2014, defined objectives of their gradual rapprochement based on common values and inseparable privileged relations, as well as strengthening the relations of Ukraine with EU policy and its participation in programs and agencies, and reinforcing the cooperation in order to ensure the supremacy of law and respect for human rights and fundamental freedoms ${ }^{2}$.

A legal position has been formed in the practice of the EU on Human Rights and other recognized international and authoritative national court instances, according to which states are prosecuted for failing to protect the inhabitants of a certain area from problems caused to the environment and public health due to activities of economic entities. The State can also be responsible for the inability to inform citizens in time about the likelihood of accidents owing to certain economic activities. Accordingly, the obligations of economic entities are: 1) acting within the Laws, rules, administrative practices in the countries, where they work, in accordance with the relevant international agreements, principles, goals, standards), taking into account the need to protect the environment, public health, security, and in general to conduct its activities in such a way as to provide more sustainable development of the country; 2) creation and supporting an environmental management system, in particular, collection and assessment the information as adequate and timely about conditions of the environment, impact of their activities on it: set goals, where it possible, those aimed at improving the environment; carry out regular monitoring and review of progress towards the set goals in the field of environmental protection, health and safety ${ }^{3}$.

In the aforementioned context, in order to implement set goals on the international level, Law of Ukraine No. 2059-VIII dated on 23.05.2017 On Environmental Impact Assessment was adopted. This Law defines the impact on the environment as any effects caused by a proposed activity on the environment, including the effects on safety of livelihoods of people and their health, flora, fauna, biodiversity, soil, air, water, climate, landscape, natural areas and objects, historical monuments and other material assets or for the totality of these factors, as well as the effects on cultural heritage or socio-economic conditions, resulting from alterations to those factors ${ }^{4}$.

The purpose of improving and developing the State Environmental Management System is also the strengthening liability for environmental damage, caused to the environment, in accordance with Ukraine's international obligations ${ }^{5}$

It should be emphasized on Law of Ukraine: On Strategic Environmental Assessment which defines the latter as a procedure of identifying, describing and evaluating effects of implementation of a public planning document

\footnotetext{
Про Основні засади (стратегію) державної екологічної політики України на період до 2030 року: Закон України від 28.02.2019 2697-VIII. Відомості Верховної Ради України від 19.04.2019. № 16 Ст. 70 .

2 Угода про асоціацію між Україною, 3 однієї сторони, та Європейським Союзом, Європейським співтовариством 3 атомної енергії і їхніми державами-членами 3 іншої сторони від 27.06.2014 № 984_011. Офіиійний вісник Украӥни від 26.09.2014. № 75. том 1, Ст. 2125.

Кошеленко К. В. (2019) Юридична відповідальність за шкоду навколишньому природному середовищу за законодавством України і ЄС: порівняльно-правовий аспект. Харків.

4 Про оцінку впливу на довкілля: Закон України від 23.05.2017 № 2059-VIII. Biдомості Верховної Ради України від 21.07.2017. № 29. Ст. 315.

5 Про основні засади (стратегію) державної екологічної політики України на період до 2030 року: Закон України від 28.02.2019 2697-VIII. Відомості Верховної Ради України від 19.04.2019. № 16 С . 70 .
} 
on the environment, including human health, reasonable alternatives and developing measures to prevent, reduce and offset possible adverse effects, which includes the scoping of strategic environmental assessment, the preparation of the strategic environmental assessment report, the carrying out of public consultations and consultations (where necessary - transboundary consultations), the taking into account of the strategic environmental assessment report and the results of public consultations and consultations in the public planning document, the provision of information on the adoption of the public planning document, and is carried out in the order determined by this Law. Effects on the environment, including human health are any likely effects on flora, fauna, biodiversity, soil, climate, air, water, landscape, natural sites and objects, safety of livelihoods of people and their health, material assets, objects of cultural heritage and the interaction among these ${ }^{6}$.

Law of Ukraine: On Environmental Protection regulates the liability issues on violation the legislation on environmental protection. Thus, Article 68 of the Law establishes disciplinary, administrative, civil, and criminal liability. In the context of this Article, we will consider criminal liability.

Crimes against the environment should be considered as socially dangerous criminal acts (actions or inactivity) that pose a threat of harm or cause real harm to the environment as an object of criminal law protection and are committed by the subject of the crime. It is possible to single out some specific signs of this type of crimes: public danger of actions; guilt of a person for committing relevant acts; illegality; the presence of the subject of a crime against the environment; the presence of the object of criminal protection ${ }^{7}$.

Criminal liability for crimes against the environment is provided by the Criminal Code of Ukraine (hereinafter referred to as CC of Ukraine). Conditionally, they can be divided into certain groups, in particular: 1) crimes in the field of environmental protection and environmental safety; 2) crimes in the field of nature management, which are internally differentiated, depending on the natural object that has been encroached (pollution or destruction of lands, illegal acquisition of grant cover (surface layer) of lands, illegal possession of water fund lands in particularly large sizes, mismanagement of lands, illegal hunting, illegal employment in fish, animal or other water mining, violation of explosive works protection of fish stocks, violation of veterinary rules, destruction or damage of flora, illegal deforestation, violation of plant protection legislation, violation of rules of protection or use of subsoil, violation of legislation on the continental shelf of Ukraine, violation of water protection rules, sea pollution, pollution atmospheric air, intentional destruction or damage of territories taken under state protection and objects of nature reserve fund); 3) environmental crimes against humanity ${ }^{8}$.

The Regulation of the Plenum of the Supreme Court of Ukraine No 17 dated 10.12. 2004 On Judicial Practice in Cases of Crimes and other Offenses Against the Environment determines Crimes and other offenses against the environment encroach on public relations in the field of the protection of the constitutional right of citizens to a safe environment, as well as in the field of protection, use, conservation and reproduction of natural resources, environmental safety, prevention and elimination of negative effects of economic and other human activities on the environment, preserving genetic

\footnotetext{
6 Про стратегічну екологічну оцінку: Закон України від 20.03.2018 № 2354-VIII. Biдомості Верховної Ради України від 20.04.2018. № 16. Ст. 138.

7 Пілюшенко Д. О. (2020) Загальна характеристика злочинів проти екологічної безпеки. Молодий учений. № 3 (79), С. 299-303 (с. 300).

8 Екологічне право : підручник / А. П. Гетьман, Г. В. Анісімова, А. К. Соколова; за заг. ред. А. П. Гетьмана. Харків, 2019. С. 228.
}

міжнародної безпеки внаслідок підвищення безпосередніх i опосередкованих ризиків пов'язаних 3 енергетичною безпекою, забезпеченням продовольством і питною водою, стабільним існуванням екосистем, ризиками для здоров'я і життя людей.

Ключові слова: довкілля, злочини проти довкілля, кримінальна відповідальність, навколишнє середовище.

O. Savchuk, V. Butenko

LEGAL REGULATION OF

CRIMINAL LIABILITY

FOR CRIMES AGAINS THE

ENVIRONMENT

The article analyzes the current legislation of Ukraine in the field of criminal liability crimes against the environment. The paper analyzes the current legislation of Ukraine in the field of criminal liability for crimes against the environment. Special attention is paid to the importance of enhancing criminal liability to ensure provided by the Constitution of Ukraine as a fundamental law and guarantor of constitutional rights and freedoms of a person and citizen, for the crimes against the environment and to compensate for the damage caused by the violation of this right.

Research methods were general scientific and (dialectical, systematic), and special scientific methods. The use of dialectical method allowed to determine the general state and research prospects of issues on legal regulation of criminal liability for crimes against the environment. The systematic method was used in the process of studying the system of legislation in the outlined issue. Regarding the special method, the formal legal method was chosen, according to which the analysis of the current legislation of acts of Ukraine in the field of criminal liability for committing crimes in the field of the environment is carried out.

Today, one of the global problems is climate change due to increasing industrial pollution (excessive concentration of environmentally hazardous industries, outdated and inefficient environmental equipment, unreliable technical systems and lack of qualified personnel in enterprises with high environmental risk), a significant number of vehicles, that do not meet environmental standards, and other factors that pollute the environment. 
All of these are significant threats to the global economy and international security due to increased direct and indirect risks related to energy security, food and drinking water supply, stable ecosystems, and risks to human health and life.

Key words: environment, crimes against environment, criminal liability.

\section{Е. А. Савчук, В. Б. Бутенко}

ПРАВОВОЕ РЕГУЛИРОВАНИЕ КРИМИНАЛЬНОЙ

ОТВЕТСТВЕННОСТИ ЗА ПРЕСТУПЛЕНИЯ ПРОТИВ ОКРУЖАЮЩЕЙ СРЕДЫ

В работе проанализировано действующее законодательство Украины в сфере криминальной ответственности за преступления против среды. внимание усиления ости дия обеспечения предусмотренного Конституцией Украины как основоположным законом и гарантом конституционных прав и свобод человека и гражданина относительно безопасной для жизни и здоровья окружающей среды и на возмещении причиненного нарушением этого права вреда.

Методами исследования были общенаучные (диалектический, системный) и специальнонаучный методы. Использование диалектического метода позволило определить общее состояние и перспективи исследования вопросов правового регулирования криминальной ответственности за преступления против окружающей среды. Системный $\mathrm{M}$ е $\mathrm{T}$ о д был использован в процессе исследования системь законодательства в определенной проблематике. Относительно специального метода, здесь был выбран метод формальноюридический, по которому проведен анализ действующего законодательства актов Украины в области криминальной ответственности за совершение преступлений в сфере окружающей природной среды.

На сегодня одной из глобальных проблем есть изменения климата в связи с усилением промышленного загрязнения (чрезмерная концентрация экологически опасных производств, устаревшее и неэффективное п р и р о до о х fund of wild-life, landscapes and other natural systems, unique territories, as well as natural objects related to historical and cultural heritage ${ }^{9}$.

This Regulation interprets the loss of human life as death of at least one person as a consequence of committing of that offence (6), endangering the life and health of people are defined when the environmental pollution or the committing of other illegal acts could lead to the death of at least one person, mass diseases of human beings, infecting at least one person, reduction of life expectancy or immune defense of people, developmental disabilities in children, etc. ( 7); liability for violation of environmental safety regulations occurs, in particular, on condition when it has caused the environmental by the results of the pollution of large areas. Such pollution should be considered a significant environmental deterioration due to considerable pollination, smoke, emissions of radioactive, chemical, bacteriological and other substances that pose a danger to humans, the environment, property, etc. (8) ${ }^{10}$.

According to M. I. Yerofeiev, there are offenses in the field of the environmental impact assessment that may become criminal in the case when, by the results of the environmental impact assessment, the permitted economic activities or building and exploitation of manufacturing facilities, in case of their negative impact on the environment, will result in the loss of human life, the environmental pollution of large areas or other serious effects. On this occasion that will be the need to establish the link between effects relevant activities and their environmental impact assessment, if the link is established. The scientist emphasized that such a link would occur when the activities that have caused significant environmental harm or losses of people will be illegal because: a) at the planning stage the activities were subjected to the environmental impact assessment, but a business entity has evaded it, and without making such an assessment and obtaining a decision on the implementation of planned activities, has started an environmentally hazardous activity; b) while making the decision, that authorized the implementation of mentioned activities (decisions of the authorized central body or the authorized territorial body to carry out the planned activity), the results of environmental impact assessment were not taken into account, which indicated the inadmissibility of its implementation; c) the decision authorizing the implementation of the relevant activities, made on the basis of taking into account the conclusion of the environmental impact assessment, which will be patently false. This causal link can be observed between noncompliance, during economic activities, with the exploitation of objects of the environmental conditions, defined in the environmental impact assessment conclusion, and with the severe environmental effects of these activities on the environment ${ }^{11}$.

It makes sense to agree with the view of the need for amendments to the legislation in force. Thus, in particular, the point is to highlight the Article in CC of Ukraine: On Violation of Legal Requirements on Environmental Impact Assessment and the scope of such compositions of offences: 1) failure to include the results of the environmental impact assessment, in accordance with the established procedure, while making the decision on the implementation of planned activities; 2) preparation of the patently false conclusion on the environmental impact assessment; 3) implementation of the planned activities that are subjected to the environmental impact assessment without making such an assessment and obtaining a decision on the implementation of planned activities; 4) non-compliance with the exploitation of objects and other interferences in the environment and landscapes during economic activities, in particular with mining operations, the use of man-made mineral deposits, defined in the environmental impact

\footnotetext{
Про судову практику у справах про злочини та інші правопорушення проти довкілля: Постанова Пленуму Верховного Суду України від 10.12.2004 № 17. URL: https:/ / zakon.rada. gov.ua/laws/show/v0017700-04\#Text

10 Там само.

11 Єрофеєв М. І. (2020) Кримінальна відповідальність за правопорушення у сфері оцінки впливу на довкілля: питання удосконалення законодавчого регулювання. Вісник ЛДУВС ім. Е. О. Дідоренка, Вип 1 (89). С. 75.
} 
assessment conclusion, the decision on the implementation of planned activities with the severe environmental effects of these activities on the environment ${ }^{12}$.

The commission of environmental crimes causes the degradation of the quality of human habitat, which leads to reduction of life expectancy, increase the morbidity, mortality rate, and easing the gene pool of the population; the formation of zones of environmental disasters and problems; degradation of renewable natural resources (fertile soils, forest resources, etc.); depletion of non-renewable natural resources (minerals, hydrocarbons); increasing risk of major man-made disasters; deterioration of surface and groundwater, coastal waters of the seas; spread of radioactive contamination; air pollution and dangerous climate change; dangerous contamination of food, as well as the growth of social tensions as a result of adverse environmental conditions ${ }^{13}$.

Noting the necessity and correctness of allocation in the CC of Ukraine in the separate paragraph Crimes against the environment, scientists notice that not all activities relating to natural features effect economic activities, public health, etc. And the relations, that are protected at the same time, are specific. Generic object of crimes against the environment is considered to be public relations concerning the conditions (relations) that ensure the existence of a multifunctional balanced unified system, its protection, rehabilitation, rational use and reproduction of such a unified system for current generations.

Also, the opinion was expressed that Section VIII of the Criminal Code should have the following title: Crimes Encroaching on Relations that Ensure Protection, Rational Use, Reproduction, and Environmental Improvement ${ }^{14}$.

At the same time, there is a proposal to amend Article 237 of the CC of Ukraine.

In particular, the indicated Article Failure to take measures to eliminate the effects on environmental pollution, directed against cases of violation of special rules on exploitation of high-risk sources in the environment, carrying out of hazardous activities that have caused severe effects (human death, pollution of significant territories, etc.), should be could Failure to take measures to prevent and eliminate the effects of environmental pollution, and its wording should be the following: Avoidance of conduct of or inadequate conduct of pollution prevention as well as failure to carry out or not to carry out pollution prevention activities in the territory exposed to hazardous substances or radiation, decontamination or other remediation of environmental pollution by a person who has caused loss of life or other serious effects, and should be punishable by restriction of liberty for a period of up to four years or deprivation of liberty for the same period with deprivation of the right to hold certain posts or engage in certain activities for a period of up to three years. Furthermore, under market relations, the criminal and financial liability of the owners of offending enterprises should be strengthened and specified ${ }^{15}$.

Law of Ukraine: On Amendments to Certain Legislative Acts of Ukraine to Protect the Environment Concerning Strengthening of the Responsibility for the Actions Directed on Air Pollution and Destruction or Damage of Objects of the Vegetative World, strengths the criminal liability in the indicated area, in particular, $\S 2$ alters sanctions for the commission of offence. Namely in

\footnotetext{
12 Єрофеєв M. I. (2020) Кримінальна відповідальність за правопорушення у сфері оцінки впливу на довкілля: питання удосконалення законодавчого регулювання. Вісник ЛДУВС ім. Е. О. Дідоренка, Вип 1 (89). С. 75.

13 Чертова Н. А. (2004) Объективные признаки преступлений против экологической безопасности водной среды и пути их совершенствования. Государство и право. № 8. С. 67.

14 Матвійчук В. К. (2005) Кримінально-правова охорона навколишнього природного середовища (кримінально-правове та кримінологічне дослідження. Київ : Азимут-Україна.

15 Барановський В. Ф. (2015) Проблема криміналізації та декриміналізації діянь, що посягають на навколишнє природне середовище. Юридична наука. № 7. С. 106.
}

оборудование,

технические

ненадежные системы и нехватка квалифицированных кадров на предприятиях с повышенным экологическим риском), значительное количество транспортных средств, которые не отвечают экологическим нормам, и другие факторы, которые загрязняют окружающую природную среду.

Все это есть существенными угрозами для глобальной экономики и международной безопасности в результате повышения непосредственных и опосредованных рисков, связанных с энергетической безопасностью, обеспечением продовольствием

питьевой водой, стабильным существованием экосистем, рисками для здоровья и жизни людей.

Ключевые слова: окружающая среда, преступления против окружающей среды, криминальная ответственность.

\section{O. Savchuk, V. Butenko}

RECHTSREGELUNG DER STRAFRECHTLICHEN VERANTWORTLICHKEIT FÜR VERBRECHEN GEGEN DIE UMWELT

In der Abhandlung analysiert man die geltende Gesetzgebung der Ukraine im Bereich der strafrechtlichen Verantwortlichkeit für Verbrechen gegen die Umwelt. Der Schwerpunkt liegt auf der Verstärkung der strafrechtlichen Verantwortlichkeit, um die Umwelt, die für Leben und Gesundheit ungefährlich ist, zu gewährleisten, was in der Verfassung der Ukraine als Grundgesetz und Garant für die verfassungsmäßigen Rechte und Freiheiten vom Menschen und Bürger vorgesehen ist, und auf der Entschädigung für Schäden, die durch die Verletzung dieses Rechts verursacht wurden.

Die Forschungsmethoden waren allgemeinwissenschaftliche (dialektische, systemische) und spezielle wissenschaftliche Methoden. Die Verwendung der dialektischen Methode ermöglichte es, den allgemeinen Stand und die Perspektiven der Forschung zur Rechtsregelung der strafrechtlichen Verantwortlichkeit für Verbrechen gegen die Umwelt zu bestimmen. Die Systemmethode wurde bei der Untersuchung des Rechtssystems in diesen Fragen verwendet. In Bezug auf die spezielle Methode wurde die formal-rechtliche Methode gewählt, nach der die Analyse 
der geltenden Gesetzgebung der Ukraine im Bereich der strafrechtlichen Verantwortlichkeit für die Begehung der Straftaten im Umweltbereich durchgeführt wird.

Eines der globalen Probleme ist heute der Klimawandel infolge der zunehmenden industriellen Verschmutzung (übermäßige Konzentration umweltgefährdender Industrien, veraltete und ineffiziente Umweltanlagen, unzuverlässige technische Systeme und Mangel an qualifiziertem Personal in Unternehmen mit hohem Umweltrisiko), die erhebliche Anzahl von Fahrzeugen, die keinen Umweltstandards entsprechen, und andere Faktoren, die die Umwelt verschmutzen.

All dies sind erhebliche Bedrohungen für die Weltwirtschaft und die internationale Sicherheit aufgrund der Erhöhung direkter und indirekter Risiken, die mit der Energiesicherheit, der Versorgung mit Lebensmitteln und Trinkwasser, stabilen Ökosystemen, Risiken für die menschliche Gesundheit und das Leben verbunden sind.

Schlüsselwörter: Umwelt Verbrechen gegen die Umwelt, strafrechtliche Verantwortlichkeit.

\section{O. Savchuk, V. Butenko}

RÉGLEMENTATION JURIDIQUE DE LA RESPONSABILITÉ PÉNALE POUR LES CRIMES CONTRE L'ENVIRONNEMENT

Le document analyse la législation actuelle de l'Ukraine dans le domaine de la responsabilité pénale pour les crimes contre l'environnement. L'accent est mis sur l'importance de renforcer la responsabilité pénale pour garantir la Constitution de l'Ukraine en tant que loi fondamentale et garante des droits et libertés constitutionnels de $l^{\prime}$ homme et du citoyen en relation avec un environnement sûr pour la vie et la santé et pour compenser les dommages causés par la violation de ce droit.

Les méthodes de recherche étaient des méthodes scientifiques générales (dialectiques, systémiques) et celles scientifiques spéciales. L'utilisation de la méthode dialectique a permis de déterminer l'état général et les perspectives des recherches sur la réglementation juridique de la responsabilité pénale pour les crimes contre l'environnement. La méthode du système a été utilisée dans le processus d'étude the Criminal Code of Ukraine (report by the Verkhovna Rada of Ukraine, No 25-26, 2001, Article 131): in Article $241 \S 2$ of the first part, the words from one hundred to two hundred should be replaced with the words from one thousand eight hundred to three thousand six hundred, in Article $245 \S$ 2 of the first part, the words from three hundred to five hundred should be replaced with the words from five thousand four hundred to nine thousand. That is, there is progress in strengthening criminal liability. We consider this the right direction in this area.

Currently, the prevention of environmental crimes against humanity is of paramount importance. This issue is regulated by the CC of Ukraine, namely Article 441 Ecocide: mass destruction of flora and fauna, poisoning of the atmosphere or water resources, as well as commission of other actions that could cause an environmental catastrophe, are punishable by imprisonment for a term of eight to fifteen years. Thus, it can be argued that Ecocide is an activity that has unavoidable effects for the environment, in which the natural environment is not restored or recovery takes a long time.

In the specialized literature an example of Ecocide has been determined as scorched earth tactics or significant destruction, damage or loss of an ecosystem in a given area, regardless of human activity or other reasons, to the extent that the peaceful coexistence of its inhabitants would be seriously jeopardized ${ }^{16}$.

Along with the term ecocide, others have appeared, such as: weather war, ecological war, geophysical war, ecological aggression, etc. However, it should be noted that the concept of ecocide is not limited to the military component and may also include criminal activity of the state in peacetime ${ }^{17}$.

Conclusions. The liability for crimes against the environment is an important component of the legal provision of the rational use of nature and the renewing of environmental objects. Its goal is to punish the perpetrators, stop and prevent violations of the law, as well as to restore the violated rights of owners of natural resources and nature users, etc.

Having analyzed the issue on legal regulation of criminal liability for crimes against the environment, we can come to the conclusion that Ukrainian legislation in some way provides an effective response in this area. However, the latter needs to be transformed in accordance with the current legal and regulatory framework which is already outdated. Ukraine is only at the beginning of this way.

In order to achieve the maximum and rapid effect, it is necessary to apply the already existing experience of the European Union countries, but necessarily in view of the peculiarities and specifics of national legislation and in accordance with the mentality of the nation.

\section{References}

Baranovs'kiy, V. F. (2015) Problema kryminalizatsiyi ta dekryminalizatsiyi diyan', shcho posyahayut' na navkolyshnye pryrodne seredovyshche. Yurydychna nauka (Eng. The problem of criminalization and decriminalization of acts that encroach on the environment. Legal science). № 7. 2015. P. 99-108. [in Ukrainian].

Ekolohichne pravo : pidruchnyk (Eng. Ecological law: textbook) / A. P. Het'man, H. V. Anisimova, A. K. Sokolova; za zah. red. A. P. Het'mana. Kharkiv, 2019. 552 p. [in Ukrainian].

Yerofeyev, M. I. (2020) Kryminal'na vidpovidal'nist' za pravoporushennya u sferi otsinky vplyvu na dovkillya (Eng. Criminal liability for offenses in the field of the environmental impact assessment): pytannya udoskonalennya zakonodavchoho rehulyuvannya. Visnyk LDUVS im. E. O. Didorenka, 2020. Vyp. 1 (89). P. 71-79. DOI: https://doi.org/10.33766/2524-0323.89.71-79 [in Ukrainian].

Koshelenko, K. V. (2019) Yurydychna vidpovidal'nist' za shkodu navkolyshn'omu pryrodnomu seredovyshchu za zakonodavstvom Ukrayiny i YES: porivnyal'nopravovyy aspekt (Eng. Legal liability for damage to the environment under the laws of Ukraine and the EU: a comparative legal aspect). Dys. kand. yuryd. nauk.

16 Спектор О. М. (2019) Міжнародно-правове регулювання сфери природоресурсних відносин: дис. доктора юрид. наук. Київ. С. 324.

17 Медведєва М. О. (2010) До питання про відповідальність в міжнародному екологічному праві. Актуальні проблеми міжнародних відносин. Випуск 93. Частина II. URL: http:/ / webcache. googleusercontent.com/search?q=cache:3tJjpmTJFEcJ:journals.iir.kiev.ua/index.php/apmv/ article $/$ download $/ 681 / 639+\& c d=2 \& h l=r u \& c t=c l n k \& g l=u a$ 
12.00.06 Zemel'ne pravo; ahrarne pravo; ekolohichne pravo; pryrodoresursne pravo. Kharkiv, 2019. 206 p. [in Ukrainian].

Matviychuk, V. K. (2005) Kryminal'no-pravova okhorona navkolyshn'oho pryrodnoho seredovyshcha (kryminal'no-pravove ta kryminolohichne doslidzhennya) (Eng. Criminal law protection of the environment (criminally-legal and criminological research): [monohrafiya]. K. : Azymut-Ukrayina, 2005. 464 p. [in Ukrainian].

Medvedyeva, M. O. (2010) Do pytannya pro vidpovidal'nist' v mizhnarodnomu ekolohichnomu pravi (Eng. On the issue of responsibility in international environmental law). Aktual'ni problemy mizhnarodnykh vidnosyn. Vypusk 93. Chastyna II. URL: http://webcache.googleusercontent.com/search?q=cache:3tjjp mTJFEcJ:journals.iir.kiev.ua/index.php/apmv/article/download/681/639+\&cd=2 \&hl=ru\&ct $=\mathrm{clnk} \& \mathrm{gl}=\mathrm{ua}$ [in Ukrainian].

Pilyushenko, D. O. (2020) Zahal'na kharakterystyka zlochyniv proty ekolohichnoyi bezpeky (Eng. General characteristics of crimes against environmental safety). Molodyy uchenyy. № 3 (79). C. 299-303. [in Ukrainian].

Pro osnovni zasady (stratehiyu) derzhavnoyi ekolohichnoyi polityky Ukrayiny na period do 2030 roku (Eng. On the basic principles (strategy) of the state environmental policy of Ukraine for the period up to 2030): Zakon Ukrayiny vid 28.02.2019 2697-VIII. Vidomosti Verkhovnoyi Rady Ukrayiny vid 19.04.2019. № 16 Ст. 70. [in Ukrainian].

Pro otsinku vplyvu na dovkillya (Eng. On Environmental Impact Assessment): Zakon Ukrayiny vid 23.05.2017 № 2059-VIII. Vidomosti Verkhovnoyi Rady Ukrayiny vid 21.07.2017. № 29. Ст. 315. [in Ukrainian].

Pro stratehichnu ekolohichnu otsinku (Eng. On Strategic Environmental Assessment): Zakon Ukrayiny vid 20.03.2018 № 2354-VIII. Vidomosti Verkhovnoyi Rady Ukrayiny vid 20.04.2018. № 16. Ст. 138. [in Ukrainian].

Pro sudovu praktyku u spravakh pro zlochyny ta inshi pravoporushennya proty dovkillya (Eng. On Judicial Practice in Cases of Crimes and other Offenses against the Environment) Postanova Plenumu Verkhovnoho Sudu Ukrayiny vid 10.12.2004 № 17. URL: https://zakon.rada.gov.ua/laws/show/v0017700-04\#Text [in Ukrainian].

Pro sudovu praktyku u spravakh pro zlochyny ta inshi pravoporushennya proty dovkillya (Eng. On Judicial Practice in Cases of Crimes and other Offenses against the Environment): Postanova Plenumu Verkhovnoho Sudu Ukrayiny vid 10.12.2004 № 17. URL: https://zakon.rada.gov.ua/laws/show/v0017700-04\#Text [in Ukrainian].

Spektor, O. M. (2019) Mizhnarodno-pravove rehulyuvannya sfery pryrodoresursnykh vidnosyn (Eng. International legal regulation of natural resource relations). Dys. doktora yuryd. nauk. Kyiv, 2019. 762 p. [in Ukrainian].

Uhoda pro asotsiatsiyu mizh Ukrayinoyu, z odniyeyi storony, ta Yevropeys'kym Soyuzom, Yevropeys'kym spivtovarystvom z atomnoyi enerhiyi i yikhnimy derzhavamy-chlenamy, z inshoyi storony (Eng. Association Agreement between Ukraine, on the one hand, and the European Union, the European Atomic Energy Community and their Member States, on the other hand) vid 27.06.2014 № 984_011. Ofitsiynyy visnyk Ukrayiny vid 26.09.2014. № 75. Volume 1. Art. 2125. [in Ukrainian].

Chertova, N. A. (2004) Ob»yektivnyye priznaki prestupleniy protiv ekologicheskoy bezopasnosti vodnoy sredy i puti ikh sovershenstvovaniya (Eng. Objective signs of crimes against ecological safety of aquatic environment and ways to improve them). Gosudarstvo i pravo. № 8. Pp. 67-72. [in Russian].

Received by Editorial Board: 16.03.2021

Suggested Citation:

Savchuk, O., Butenko, V. (2021). Legal Regulation of Criminal Liability for Crimes Agains the Environment. Archives of Criminology and Forensic Sciences. 1(3). 89-95. DOI: https://doi.org/10.32353/acfs.3.2021.09 du système de législation dans les questions décrites. En ce qui concerne la méthode spéciale, la méthode formelle-juridique a été choisie. Selon cette méthode l'analyse de la législation actuelle des actes de l'Ukraine dans le domaine de la responsabilité pénale pour les crimes dans le domaine de l'environnement est effectuée.

A l'heure actuelle, l'un des problèmes mondiaux est le changement climatique dû à l'augmentation de la pollution industrielle (concentration excessive d'industries dangereuses pour l'environnement, équipements environnementaux obsolètes et inefficaces, systèmes techniques peu fiables et manque de personnel qualifié dans les entreprises à haut risque environnemental), un nombre important de véhicules qui ne respectent pas les normes environnementales et d'autres facteurs qui polluent l'environnement.

Tous ces éléments constituent des menaces importantes pour l'économie mondiale et la sécurité internationale en raison de l'augmentation des risques directs et indirects liés à la sécurité énergétique, à l'approvisionnement alimentaire et en eau potable, à la stabilité des écosystèmes et aux risques pour la santé et la vie humaines.

Mots-clés : environnement, crimes contre environnement, responsabilité pénale, environnement. 